\title{
Single-center Experiences of Ovarian Sex Cord Stromal Tumors
}

\section{Ovaryan Seks Kord Stromal Tümörlerin Tek Merkez Deneyimleri}

\author{
(D) Özlem Karabay Akgül, (D) Evrim Ebru Kovalak, (D) Yasin Ceylan, (D) Gamze Taşkıran, (D) Metehan Uzundal, \\ (D) Taylan Şenol
}

University of Health Sciences Turkey, İstanbul Bağcllar Training and Research Hospital, Clinic of Obstetrics and Gynecology, İstanbul, Turkey

\section{Abstract}

Objective: The aim of this study is to examine the sex cord stromal tumors of the ovary operated in our clinic in the last 4 years and to contribute to the literature on this rare tumor.

Method: The clinical and laboratory findings of 34 patients with pathological diagnosis of ovarian sex cord stromal tumor, who were operated in our obstetrics and gynecology clinic between 2016 and 2020, were evaluated retrospectively. Pathological diagnoses were classified and other accompanying pathologies and complaints were evaluated for each type.

Results: Ovarian sex cord stromal tumors usually attract attention with the peripheral effects of the hormones produced by the tumor tissue. They rarely come to very large sizes. They are mostly benign. When the hormone estrogen is produced, accompanying endometrial pathologies should not be overlooked. Hormonal complaints in patients improve dramatically after surgery both clinically and laboratory. Oncological follow-up is required following diagnosis in some malignant types.

Conclusion: If ovarian sex cord stromal tumor is suspected, preoperative blood androgen levels, inhibin A, and alpha feto protein (AFP) should be evaluated. In addition, ultrasonographic and, if necessary, endometrial histopathological evaluations are important for patient follow-up as well as diagnosis. The patient's fertility desire and age should be considered during treatment.

Keywords: Endocrinologic changes, ovarian mass, sex cord stromal ovarian tumors

\section{Öz}

Amaç: Bu çalışmanın amacı kliniğimizde son 4 yılda ameliyat edilen overin seks kord stromal tümörlerini incelemek ve nadir görülen bu tümör ile ilgili literatüre katkı sağlamaktır.

Yöntem: 2016-2020 yılları arasında kadın hastalıkları ve doğum kliniğimizde opere edilen ve patolojik tanısı ovaryan seks kord stromal tümör olan 34 hastanın klinik, laboratuvar bulguları geriye dönük olarak değerlendirildi. Patolojik tanılar sınıflandırıldı ve eşlik eden diğer patolojiler ve şikayetleri her tip için değerlendirildi.

Bulgular: Ovaryan seks kord stromal tümörleri çoğunlukla tümör dokusunun ürettiği hormonların periferik etkileri ile dikkat çeker. Çok büyük boyutlara nadir gelirler. Çoğunlukla iyi huyludurlar. Üretilen hormon östrojen olunca hastada eşlik eden endometrial patolojiler gözden kaçırımamalıdır. Hastalardaki hormonal şikayetler klinik ve laboratuvar olarak ameliyat sonrası dramatik olarak düzelir. Bazı malign tiplerde tanıyı takiben onkolojik takip gereklidir.

Sonuç: Ovaryan seks kord stromal tümörü şüphesi halinde preoperatif kan androjen seviyeleri, inhibin A, alfa fetoprotein değerlendirilmelidir. Ayrıca ultrasonografik ve gerektiği taktirde endometrial histopatolojik değerlendirme tanının yanı sıra hasta takibi için önemlidir. Hastanın fertilite isteği ve yaşı tedavi esnasında önemsenmelidir.

Anahtar kelimeler: Endokrin değişiklikler, ovaryan kitle, ovaryan seks kord stromal tümörleri

Address for Correspondence: Özlem Karabay Akgül, University of Health Sciences Turkey, İstanbul Bağcılar Training and Research Hospital, Clinic of Obstetrics and Gynecology, İstanbul, Turkey

E-mail: ozlem74akgul@hotmail.com ORCID: orcid.org/0000-0003-0313-1893 Received: 12.08.2021 Accepted: 10.11.2021

Cite this article as: Karabay Akgül Ö, Kovalak EE, Ceylan Y, Taşkıran G, Uzundal M, Şenol T. Single-center Experiences of Ovarian Sex Cord Stromal Tumors. Bagcilar Med Bull 2021;6(4):413-418

${ }^{\circ}$ Copyright 2021 by the Health Sciences University Turkey, Bagcilar Training and Research Hospital Bagcilar Medical Bulletin published by Galenos Publishing House. 


\section{Introduction}

Sex cord-stromal tumors of the ovary (SCST) are rare tumors arising from stromal cells outside the follicular tissue of the ovary and can be benign or malignant. Ovarian SCSTs are almost always unilateral, but $1.5 \%$ are bilateral. Ovarian SCST is less common than epithelial or germ cell origins, benign ovarian SCSTs account for $4 \%$ of benign neoplasms of the ovary, malignant forms are less than $8 \%$ of malignant neoplasms of the ovary (1).

Malignant forms of SCSTs are rarely encountered and if there is a malignant SCST, it is generally diagnosed at early stages because of the clinical effects of hormones that are produced by the tumor itself. Most of the malignant forms have a histologically low grade and good prognosis (2).

SCSTs are divided into 3 categories: Pure stromal tumors, mixed cord tumors, mixed-sex cord-stromal tumors. SCSTs are observed in a wide range of ages and they often produce steroid hormones [especially androgens, estrogens (E), cortisone] with symptoms varying up to hormones related (3). Whenever androgen levels are above normal, menstrual irregularity (especially oligomenorrhea/ amenorrhea), hirsutism, and even virilization may occur.

Estrogen elevation can lead to abnormal uterine bleeding, endometrial hyperplasia, postmenopausal bleeding, and puberty praecox in children. The patient can complain of abdominal and pelvic pain. In some cases, it can be noticed during a gynecological examination.

In this study, we aimed to share our single-center experiences about SCST over the past four years.

\section{Materials and Methods}

Documents of 34 patients with pathological diagnoses of ovarian SCST were reviewed retrospectively. The patients, who applied to our gynecology and obstetrics outpatient clinic from January 2016 to January 2020, were diagnosed with an ovarian mass, underwent surgical treatment, and had a pathological diagnosis of ovarian SCST, were included in our study. This retrospective study was initiated following the decision of the Ethics Committee of İstanbul Medipol University, Non-Interventional Clinical Research, dated 20.05.2021 and numbered 484. The patients' age, parity, clinical complaints, ultrasonographic findings, menstrual patterns, results of additional diagnostic methods, and hormone test results were recorded. Signs and symptoms such as abdominal pain, dyspareunia, bloating, constipation, hairiness, clitoromegaly, voice change, and pain were evaluated retrospectively. Type of the tumor, its largest diameter, number of pathological masses, and the type of surgery performed with the menstrual pattern in menstruating patients and its duration were recorded. Pathological diagnoses of all patients were grouped. The clinical changes and complaints during the postoperative period were also questioned.

\section{Statistical Analysis}

As a statistical calculation, only the percentage was calculated, that is, no special test was used.

\section{Results}

Between the years of 2016 and 2020, 34 female patients were diagnosed with pathological ovarian SCST. The clinical and laboratory findings of the patients before the operation are summarized in Table 1, 2. The ovaries of the patients were evaluated by ultrasonography, and their size and appearance were recorded. There was no significant increase in preoperative CA12-5, CA19-9, AFP, and human corionic gonadotropin (hCG) levels.

The age of patients varied between 15 and 78 years. The median age was calculated as 55 years. While the 15 -yearold patient with granulosa cell tumor (GCT) had never been pregnant, the maximum number of parity was 13 in all groups and the median parity count was 3 . One of the patients with Leydig cell tumor was also infertile.

Eighteen patients were in the menopause period. Among 16 premenopausal patients, 6 of them were normally menstruating patients, while 4 patients were complaining from polymenorrhea, 3 patients (8.82\%) were oligomenorheaic and remaining 3 (8.82\%) were amenorheic.

Among 34 patients, 6 patients $(17.65 \%)$ had hirsutism (Ferriman-Gallwey score $>8$ points) and 2 patients $(5.88 \%$ ) had hyperandrogenemia findings except for hirsutism (oligomenorrhea, amenorrhea, clitoromegaly, voice change). Patients without hormonal findings were suffering from mild abdominal pain and bloating.

Androgen hormone levels were measured in 8 patients with hyperandrogenemic symptoms (such as oligomenorrhea, amenorrhoea, clitoromegaly, voice change, hirsutism) and were found above the normal range in 2 of them. In the patient with Leydig cell tumor, whose preoperative serum testosterone (T) level was $9 \mathrm{ng} / \mathrm{mL}$, postoperative value decreased to $2 \mathrm{ng} / \mathrm{mL}$ on the first following day. 
Table 1. The age range distribution according to tumor

types, the parity of the patients and the largest size of the mass measured on ultrasonography

\begin{tabular}{|c|c|c|c|c|}
\hline TM type & & Age & Parity & $\begin{array}{l}\text { Tm } \\
\text { diameter }\end{array}$ \\
\hline \multirow[t]{6}{*}{ Fibroma } & $\mathbf{N}$ & 5 & 5 & 5 \\
\hline & Mean & 53.2 & 3.8 & 6.5 \\
\hline & SD & 13.81 & 2.05 & 3.74 \\
\hline & Median & 54 & 4 & 5 \\
\hline & Minimum & 31 & 2 & 3 \\
\hline & Maximum & 67 & 7 & 11 \\
\hline \multirow[t]{6}{*}{ Fibrothecoma } & $\mathbf{N}$ & 12 & 12 & 12 \\
\hline & Mean & 57.83 & 5.33 & 8.79 \\
\hline & SD & 13.08 & 3.94 & 4.77 \\
\hline & Median & 58 & 4.5 & 8.5 \\
\hline & Minimum & 33 & 1 & 3 \\
\hline & Maximum & 78 & 13 & 16 \\
\hline \multirow[t]{6}{*}{ Tecomata } & $\mathbf{N}$ & 1 & 1 & 1 \\
\hline & Mean & 51 & 3 & 7 \\
\hline & SD & . & . & . \\
\hline & Median & 51 & 3 & 7 \\
\hline & Minimum & 51 & 3 & 7 \\
\hline & Maximum & 51 & 3 & 7 \\
\hline \multirow[t]{6}{*}{ Steroid HC tm } & $\mathbf{N}$ & 1 & 1 & 1 \\
\hline & Mean & 63 & 10 & 4 \\
\hline & SD & . & . & . \\
\hline & Median & 63 & 10 & 4 \\
\hline & Minimum & 63 & 10 & 4 \\
\hline & Maximum & 63 & 10 & 4 \\
\hline \multirow[t]{6}{*}{ Granulosa } & $\mathbf{N}$ & 10 & 10 & 10 \\
\hline & Mean & 43.5 & 2.6 & 8.3 \\
\hline & SD & 20.38 & 2.22 & 5.22 \\
\hline & Median & 46.5 & 2 & 7.5 \\
\hline & Minimum & 15 & 0 & 2 \\
\hline & Maximum & 71 & 7 & 19 \\
\hline \multirow{6}{*}{$\begin{array}{l}\text { Sex cord with } \\
\text { annuler tubules }\end{array}$} & $\mathbf{N}$ & 1 & 1 & 1 \\
\hline & Mean & 42 & 3 & 17 \\
\hline & SD & . & . & . \\
\hline & Median & 42 & 3 & 17 \\
\hline & Minimum & 42 & 3 & 17 \\
\hline & Maximum & 42 & 3 & 17 \\
\hline \multirow{6}{*}{$\begin{array}{l}\text { Fibroma with minor } \\
\text { sex cord elements }\end{array}$} & $\mathbf{N}$ & 1 & 1 & 1 \\
\hline & Mean & 34 & 1 & 13 \\
\hline & SD & . & . & . \\
\hline & Median & 34 & 1 & 13 \\
\hline & Minimum & 34 & 1 & 13 \\
\hline & Maximum & 34 & 1 & 13 \\
\hline
\end{tabular}

\section{Table 1. Continued}

\begin{tabular}{|c|c|c|c|c|}
\hline TM type & & Age & Parity & $\begin{array}{l}\text { Tm } \\
\text { diameter }\end{array}$ \\
\hline \multirow{6}{*}{$\begin{array}{l}\text { Sclerosing stromal } \\
\text { tm }\end{array}$} & $\mathbf{N}$ & 1 & 1 & 1 \\
\hline & Mean & 39 & 3 & 7 \\
\hline & SD & . & . & . \\
\hline & Median & 39 & 3 & 7 \\
\hline & Minimum & 39 & 3 & 7 \\
\hline & Maximum & 39 & 3 & 7 \\
\hline \multirow{6}{*}{$\begin{array}{l}\text { Sex cord stromal } \\
\text { tm }\end{array}$} & $\mathbf{N}$ & 1 & 1 & 1 \\
\hline & Mean & 63 & 7 & 5 \\
\hline & SD & . & . & . \\
\hline & Median & 63 & 7 & 5 \\
\hline & Minimum & 63 & 7 & 5 \\
\hline & Maximum & 63 & 7 & 5 \\
\hline \multirow[t]{6}{*}{ Leydig HC tm } & $\mathbf{N}$ & 1 & 1 & 1 \\
\hline & Mean & 37 & 0 & 5 \\
\hline & SD & . & . & . \\
\hline & Median & 37 & 0 & 5 \\
\hline & Minimum & 37 & 0 & 5 \\
\hline & Maximum & 37 & 0 & 5 \\
\hline \multirow[t]{6}{*}{ All patient groups } & $\mathbf{N}$ & 34 & 34 & 34 \\
\hline & Mean & 50.71 & 4 & 8.21 \\
\hline & SD & 16.07 & 3.24 & 4.64 \\
\hline & Median & 55 & 3 & 7 \\
\hline & Minimum & 15 & 0 & 2 \\
\hline & Maximum & 78 & 13 & 19 \\
\hline
\end{tabular}

SD: Standard deviation

In the study group, the most frequent pathology was fibrothecoma, which was diagnosed in 12 patients (35.29\%), and the second common one was GCT in 10 patients (29.41\%).

Sclerosing cell tumor and fibrothecoma were detected as multiple foci, while other cases were diagnosed as a single mass. Polymenorrhea, which may be a sign of hyperestrogenemia, was observed in patients with GCTs, thecoma, and fibrothecoma.

The diameter of the masses was evaluated by ultrasonography (using the General Electric Logiq C3 Premium device). The detected range of masses was from 2 to $19 \mathrm{~cm}$, and the median value was calculated as $7 \mathrm{~cm}$. All SCSTs were unilateral except for 2 patients.

All patients underwent surgical treatment. Hysterectomy (laparoscopic or by laparotomy) and bilateral salpingooophorectomywereperformedin 16 (47.6\%), oophorectomy in 12 (35.29\%), and cystectomy in 6 patients (17.65\%). 
Table 2. The numerical classification of tumors and clinical complaints and types of surgery (hyperandrogenism only shows patients with high laboratory value)

\begin{tabular}{|c|c|c|c|}
\hline & & $\mathbf{n}$ & $\%$ \\
\hline \multirow[t]{10}{*}{ TM type } & Fibroma & 5 & 14.71 \\
\hline & Fibrothecoma & 12 & 35.29 \\
\hline & Tecomata & 1 & 2.94 \\
\hline & Steroid HC tm & 1 & 2.94 \\
\hline & Granulosa & 10 & 29.41 \\
\hline & Sex cord with annular tubules & 1 & 2.94 \\
\hline & $\begin{array}{l}\text { Fibroma with minor sex cord } \\
\text { elements }\end{array}$ & 1 & 2.94 \\
\hline & Sclerosing stromal tm & 1 & 2.94 \\
\hline & Sex cord stromal tm & 1 & 2.94 \\
\hline & Leydig hc tm & 1 & 2.94 \\
\hline \multirow[t]{5}{*}{ Menstrual pattern } & Menopause & 18 & 52.94 \\
\hline & Oligomenorrhea & 3 & 8.82 \\
\hline & Polymenorrhea & 4 & 11.76 \\
\hline & Amenorrhea & 3 & 8.82 \\
\hline & Normal & 6 & 17.65 \\
\hline \multirow[t]{2}{*}{ Hyperandrogenism } & None & 32 & 94.12 \\
\hline & Yes & 2 & 5.88 \\
\hline \multirow[t]{2}{*}{ Hirsutism } & None & 28 & 82.35 \\
\hline & Yes & 6 & 17.65 \\
\hline \multirow[t]{2}{*}{ TM number } & Single & 32 & 94.12 \\
\hline & Multiple & 2 & 5.88 \\
\hline \multirow[t]{3}{*}{ Surgical type } & Cystectomy & 6 & 17.65 \\
\hline & Oophorectomy & 12 & 35.29 \\
\hline & Hysterectomy+oophorectomy & 16 & 47.06 \\
\hline
\end{tabular}

No recurrence was observed in any patient. Chemotherapy was given only to 1 patient with a pathological diagnosis of GCT.

We detected endometrial pathology accompanying ovarian SCST in 7 patients. These endometrial pathologies were seen as early-stage endometrial cancer in 2 patients, endometrial hyperplasia with atypia in 1 patients, endometrial hyperplasia without atypia in 2 patients, and endometrial polyp in 2 patients. Both endometrial cancer cases were stage 1A FIGO grade 2 endometrioid cancer and one of them had AGCT and the other had fibrothecoma. A squamous cell component was also detected in the endometrial specimen in the case of fibrothecoma and endometrial cancer.

One of the patients with endometrial polyp was accompanied by ovarian thecoma and the other by GCT. Fibrothecoma in one case and AGCT in the other were detected in the ovary of the cases with endometrial hyperplasia without atypia. Ovarian AGCT was observed in the patient who had hyperplasia with atypia.

\section{Discussion}

Ovarian SCSTs are rare tumors and in the literature, there are not many studies with large patient groups on this subject. We aimed to classify our patients with a definite diagnosis of postoperative pathology in terms of their preoperative findings and to reveal the symptoms that should be kept in mind in the preliminary diagnosis. Most patients with SCSTs need to be operated regardless of tumor size due to endocrine complaints.

The important thing is to choose the most appropriate treatment for the patient. Considering that it is frequently seen in patients at the end of the reproductive age, it may be good to postpone the operation that will affect the ovarian reserve or to plan the operation early for the treatment of infertility in women of reproductive age.

Since SCSTs are rarely seen, publications on postoperative long-term follow-up are also limited.

When SCSTs are evaluated together with an adnexal mass, accompanying hormonal clinical findings, and some laboratory features, diagnosis becomes easier. In laboratory examination, blood levels of reproductive hormones such as estrogen and testosterone, and blood levels of tumor markers such as inhibin A and B and AFP may be useful (4). AFP, E2, inhibin (A and B), T, A4, DHEAS, and CA 125 generally do not elevate in Sertoli Leydig cell tumors (5).

Polymenorrhea, which may be a sign of hyperestrogenism, has been observed in GCTs, thecoma, and fibrothecoma.

In the literature, the rates of endometrial hyperplasia and endometrial cancer associated with $\mathrm{E}$ produced from ovarian mass in the presence of ovarian GCT were found to be $50 \%$ and $10 \%$, respectively (6). In our patients' group, we found endometrial pathologies accompanying adult-type granulosa cell tumor (AGCT), thecoma and fibrothecoma. In our study group, endometrial cancer in fibroma case, hyperplasia without endometrial atypia in fibrothecoma case, and endometrial polyp in our thecoma patient were seen. If there is a mass in the ovary, it should be kept in mind that the tumor type may be SCST in premenopausal women with abnormal uterine bleeding and in women with menopausal bleeding complaints.

Preoperative endometrial sampling should be performed in the presence of endometrial thickness more than $5 \mathrm{~mm}$ on ultrasonography in a postmenopausal woman with uterine 
bleeding and presence of irregular and thick endometrium, breakthrough bleeding, and irregular bleeding in a premenopausal woman for the screening of endometrial pathologies.

Fibrothecoma is a rare tumor in all ovarian tumors. In our study, the most common tumor was fibrothecoma, with a rate of $35.29 \%$ ( 12 cases). The absence of exact criteria in the pathological diagnosis of fibrothecoma may have changed the frequency of diagnosis. GCT was seen in second place with $29.41 \%$ (10 cases). In the literature, $2-5 \%$ of all ovarian cancers are GCT (6).

SCSTs are mostly seen over the age of 50 years (7). In our study, menopausal patients were in the majority and this is consistent with the literature (52.94\%). In the study group, there was no significant difference among the tumor groups in terms of menstrual pattern, and there were even patients with normal menstrual cycles.

Some types of SCST present with endocrine symptoms rather than mass effects. In our study group, we mostly have not seen the clinical signs of hyperandrogenemia.

SCSTs are mostly unilateral and not very large masses, rarely reaching $10-15 \mathrm{~cm}$. Two $(5.88 \%)$ of 34 patients had multiple masses, and the remaining 32 ones $(94.12 \%)$ had a single mass. Some SCST types present with endocrine symptoms rather than mass effects.

Nowadays, SCSTs are treated in the same way as ovarian germ cell tumors and epithelial tumors. Only genetic mutation existence should be considered during treatment (4).

The most malignant form of SCSTs is AGCT, which may closely resemble the surface epithelial tumors. It may even be confused with endometrioid ovarian carcinoma on microscopic examination (8).

In the pathological examination, SCSTs may be cystic with solid components, lobulated, soft, and fragile. These masses may present with functional findings without the effect of intra-abdominal mass such as abdominal distension and constipation. Hyperandrogenism up to virilization has been reported in the literature, and especially in hirsutism that starts suddenly and increases rapidly, androgenic hormones and tumor markers should be checked in addition to the examination with trans vaginal ultrasonography of the ovaries. Women with breast tightness, bleeding abnormalities should be screened for SCST in detail. Any existing GCT should be operated without delay because of its malignant potential. In the presence of hormonal findings accompanying a solid mass in the ovary in adolescent patients, the patient's future fertility should be considered, and tumor markers should be followed up preoperatively and after treatment. In addition, genetic consultation should be done in terms of genetic mutations and other family members should be warned. There is no correlation between virilization level and serum androgen levels, but it should be remembered that cell type and tumor size correlate with clinical findings (8).

In our study, other gynecological cancers that might accompany ovarian SCSTs caught our attention. However, the limited patient count prevents us from explaining the relationship between SCST and cancer. Therefore, studies with larger case numbers are needed.

The small number of patients in the study is the most important limiting factor, and the presence of rare pathological types is insufficient to explain the relationship between tumor type and clinical picture. Due to the low prevalence of these tumors, even a small number of case groups are valuable to have an idea about their clinical picture.

\section{Conclusion}

In this study, we wanted to emphasize the necessity of evaluating the clinical findings of women with solid ovarian masses and to contribute to the literature by measuring preoperative blood androgen levels and tumor markers such as inhibin A and AFP that may be useful in postoperative patient follow-up.

\section{Ethics}

Ethics Committee Approval: This retrospective study was initiated following the decision of the Ethics Committee of İstanbul Medipol University, Non-Interventional Clinical Research, dated 20.05.2021 and numbered 484 .

Informed Consent: Consent was obtained from the patients participating in the study.

Peer-review: Externally and internally peer-reviewed.

\section{Authorship Contributions}

Concept: Ö.K.A., G.T., T.Ş., Design: Ö.K.A., G.T., T.Ş., Data Collection or Processing: Ö.K.A., E.E.K., Y.C., G.T., M.U., Analysis or Interpretation: Ö.K.A., Y.C., T.Ş., M.U., E.E.K., Drafting Manuscript: Ö.K.A., E.E.K., Y.C., G.T., M.U., T.Ş., Critical Revision of Manuscript: Ö.K.A., E.E.K., Y.C., T.Ş., G.T., Final Approval and Accountability: Ö.K.A., E.E.K., Y.C., T.Ş. 


\section{Conflict of Interest: No conflict of interest was declared by} the authors.

Financial Disclosure: The authors declared that this study received no financial support.

\section{References}

1. Quirk JT, Natarajan N. Ovarian cancer incidence in the United States, 1992-1999. Gynecol Oncol 2005;97(2):519-523.

2. Brown J, Sood AK, Deavers MT, Milojevic L, Gershenson DM. Patterns of metastasis in sex cord-stromal tumors of the ovary: can routine staging lymphadenectomy be omitted? Gynecol Oncol 2009;113(1):86-90.

3. Varras M, Vasilakaki T, Skafida E, Akrivis C. Clinical, ultrasonographic, computed tomography and histopathological manifestations of ovarian steroid cell tumour, not otherwise specified: our experience of a rare case with female virilisation and review of the literature. Gynecol Endocrinol 2011;27(6):412-418.
4. Schultz KA, Harris AK, Schneider DT, Young RH, Brown J, Gershenson DM, et al. Ovarian sex cord-stromal tumors. J Oncol Pract 2016;12(10):940-946.

5. Gomes TA, Campos EA, Yoshida A, Sarian LO, Andrade LALA, Derchain SF. Preoperative differentiation of benign and malignant non-epithelial ovarian tumors: clinical features and tumor markers. Rev Bras Ginecol Obstet 2020;42(9):555-561.

6. Ottolina J, Ferrandina G, Gadducci A, Scollo P, Lorusso D, Giorda G, et al. Is the endometrial evaluation routinely required in patients with adult granulosa cell tumors of the ovary? Gynecol Oncol 2015;136(2):230-234.

7. Young RH. Ovarian sex cord-stromal tumours and their mimics. Pathology 2018;50(1):5-15.

8. Sehemby M, Bansal P, Sarathi V, Kolhe A, Kothari K, JadhavRamteke S, et al. Virilising ovarian tumors: a single-center experience. Endocr Connect 2018;7(12):1362-1369. 